\title{
ERRATA
}

\section{Importância da conservação in situ de Copaifera langsdorffii Desf. em remanescentes de cerrado de propriedades particulares rurais}

A espécie arbórea Copaifera langsdorffii foi utilizada no presente estudo para verificar a estrutura demográfica populacional, a diversidade genética e o fluxo gênico aparente entre os remanescentes de cerrado localizados em Unidades de Conservação (UCs) e em propriedades particulares rurais (PPRs) no Estado de São Paulo. Para tanto, utilizou-se oito locos microssatélites nucleares específicos de C. langsdorffii; e foram mapeados, mensurados e genotipados ao todo 400 indivíduos com DAP $\geq 5 \mathrm{~cm}$ em quatro áreas nas cidades de Assis, Itirapina e Brotas. Em Assis foram amostrados 100 indivíduos na Estação Ecológica de Assis (EEA) e 100 indivíduos em uma PPR a $13 \mathrm{~km}$ de distância da EEA. Em Itirapina 100 indivíduos foram amostrados na Estação Ecológica de Itirapina (EEI) e 100 indivíduos numa PPR em Brotas a $24 \mathrm{~km}$ de distância da EEI. As populações em propriedade particulares rurais e unidades de conservação apresentaram alta diversidade genética. Contudo as PPRs tiveram um número maior de alelos exclusivos do que as UCs, indicando que as populações nas PPRs necessitam urgentemente de planos de manejo para conservar esses alelos exclusivos que podem conferir às populações do cerrado vantagens adaptativas. Todas as populações apresentaram fraca estrutura genética espacial, porém significativa por volta de 20 $\mathrm{m}$ de distância, indicando uma dispersão restrita de sementes. Foi observado nas populações analisadas um alto índice de fixação que, provavelmente, deve-se à sobreposição de gerações. A estimativa do tamanho efetivo das populações sugere que tanto as UCs quanto as PPRs têm área mínima viável para a conservação in situ das respectivas populações. A divergência genética entre as populações foi alta segundo o estimador $G_{S T}{ }^{\prime}$ e o fluxo gênico aparente entre as UCs e PPRs foi baixo, sendo insuficiente para contrapor os efeitos da deriva genética. A alta porcentagem de alelos raros encontrados nas populações, provavelmente, evidencia o comprometimento das mesmas com a perda de diversidade genética, através da deriva genética. É fundamental a conservação de remanescentes de cerrado em áreas particulares rurais, para que seja mantida a manutenção do potencial evolutivo da espécie no longo prazo.

Palavras-chave: Cerrado; Fragmentos; Copaíba; Diversidade genética; Fluxo gênico; Microssatélites 